\title{
URINARY AND INTESTINAL SYMPTOMS IN PUBLIC ELEMENTARY SCHOOL CHILDREN
}

\author{
Camilla Pinheiro Cristaldi da Silva ${ }^{1} \mathbb{D}$, Juliane Nascimento Ribas Miranda $\mathbb{B}^{\mathbb{B}}$, \\ Drielle Fernanda Arruda2,* (D), Gisele Martins 3 (D), Gisela Maria Assis 4 (D)
}

\begin{abstract}
Objective: survey the occurrence of urinary and intestinal symptoms in children from public elementary schools in the capital of Paraná. Method: quantitative, exploratory-descriptive and cross-sectional study. Sample of parents/guardians who completed the following instruments: Dysfunctional Voiding Scoring System; Rome IV criteria; Bristol scale. Analysis performed by IBM SPSS Statistics v.20.0. Data were collected from August to October 2019. Inclusion criteria were the child being enrolled and regularly attending elementary school and the delivery of the completed or partially completed questionnaire. Results: 458 questionnaires were delivered. Of those fully completed, $51.9 \%$ were girls, and the age was 7.7 years; $83 \%$ of the children had some urinary and/or intestinal symptoms of low severity. There was no significant difference in symptoms between genders, and with a significant increase in severity in children aged 7 years and under. Most prevalent symptoms: reduced voiding frequency, reduced defecation frequency, defecation effort, voiding urgency and containment maneuvers; 39.6\% of the children had Functional Intestinal Constipation. Bladder and bowel dysfunction in 35 children, the highest prevalence in females. Conclusion: high occurrence of urinary and intestinal symptoms in children. The most prevalent symptom was constipation.
\end{abstract}

DESCRIPTORS: Child health. Urinary incontinence. Intestinal constipation. Stomatherapy.

\section{SINTOMAS URINÁRIOS E INTESTINAIS EM CRIANÇAS DA REDE PÚBLICA DE ENSINO FUNDAMENTAL}

\section{RESUMO}

Objetivo: levantar a ocorrência de sintomas urinários e intestinais em crianças da rede pública de ensino fundamental da capital paranaense. Método: estudo quantitativo, exploratório-descritivo e de corte transversal. Amostra de pais/responsáveis que preencheram os seguintes instrumentos: Dysfunctional Voiding Scoring System; critérios de Roma IV; escala de Bristol. Análise realizada pelo IBM SPSS Statistics v.20.0. Os dados foram coletados no período de agosto a outubro de 2019. Os critérios de inclusão eram a criança estar matriculada e frequentando regularmente o ensino fundamental e a entrega do questionário preenchido ou parcialmente preenchido. Resultados: Foram entregues 458 questionários. Dos totalmente preenchidos, 51,9\% era de meninas, e a de idade foi de 7,7 anos; $83 \%$

1. Pontifícia Universidade Católica do Paraná - Especialização em Enfermagem em Estomaterapia - Curitiba (PR), Brazil.

2. Universidade Federal do Paraná - Departamento de Cirurgia - Programa de Pós-graduação em Clinica Cirúrgica Curitiba(PR), Brazil.

3. Universidade de Brasília - Departamento de Enfermagem - Curso de graduação e pós- graduação em Enfermagem Brasília (DF), Brazil.

4. Universidade de Brasilia - Departamento de Enfermagem - Programa de Pós-graduação em Enfermagem - Brasilia (DF), Brazil. *Correspondence author: arruda.drielle@gmail.com

Section Editor: Juliano Teixeira Moraes

Received: Out. 18, 2021 | Accepted: Dez. 16, 2021

How to cite: Silva CPC; Miranda JNR; Arruda DF; Martins G; Assis GM. Urinary and intestinal symptoms in public elementary school children. ESTIMA, Braz. J. Enterostomal Ther., 2021, 19: e3021. https://doi.org/10.30886/estima.v19.1140_IN 
das crianças apresentaram algum sintoma urinário e/ou intestinal de baixa gravidade. Sem diferença significativa de sintomas entre sexos, e com acréscimo significativo de gravidade em crianças com 7 anos ou menos. Sintomas mais prevalentes: frequência miccional reduzida, frequência evacuatória reduzida, esforço evacuatório, urgência miccional e manobras de contenção; 39,6\% das crianças apresentavam Constipação Intestinal Funcional. Disfunção vesical e intestinal em 35 crianças, a maior prevalência no sexo feminino. Conclusão: alta ocorrência de sintomas urinários e intestinais nas crianças. O sintoma mais prevalente foi constipação.

DESCRITORES: Saúde da criança. Incontinência urinária. Constipação intestinal. Estomaterapia.

\section{SÍNTOMAS URINARIOS E INTESTINALES EN NIÑOS DE ESCUELAS PRIMARIAS PÚBLICAS}

\section{RESUMEN}

Objetivo: relevar la ocurrencia de síntomas urinarios e intestinales en niños de escuelas primarias públicas de la capital paranaense. Método: estudio cuantitativo, exploratorio-descriptivo y de corte transversal. Muestra de padres/ responsables que completaron los siguientes instrumentos: Dysfunctional Voiding Scoring System; criterios de Roma IV; escala de Bristol. Análisis realizado por el IBM SPSS Statistics v.20.0. Los datos fueron recopilados en el periodo de agosto a octubre de 2019. Los criterios de inclusión eran de niños matriculados y que frecuenten regularmente la escuela primaria y la entrega del cuestionario completo o parcialmente completo. Resultados: Se entregaron 458 cuestionarios. De los totalmente completos, 51,9 \% era de niñas, y la de edad fue de 7,7 años; 83 \% de los niños presentaron algún síntoma urinario y/o intestinal de baja gravedad. Sin diferencia significativa de síntomas entre sexos, y con incremento significativo de gravedad en niños de 7 años o menos. Síntomas más prevalentes: frecuencia miccional reducida, frecuencia evacuatoria reducida, esfuerzo evacuatorio, urgencia miccional y maniobras de contención; 39,6 \% de los niños presentaban Constipación Intestinal Funcional. Disfunción vesical e intestinal en 35 niños, la mayor prevalencia en el sexo femenino. Conclusión: alta ocurrencia de síntomas urinarios e intestinales en niños. El síntoma más prevalente fue el estreñimiento.

DESCRIPTORES: Salud del niño. Incontinencia urinaria. Estreñimiento intestinal. Estomaterapia.

\section{INTRODUCTION}

There is a strong association between lower urinary tract symptoms (LUTS) and bowel symptoms in the pediatric population. Thus, the International Children's Continence Society (ICCS) defines a broad term called bladder and bowel dysfunction (BBD) as a group of symptoms that include bladder changes associated with symptoms of bowel functioning ${ }^{1,2}$.

Among some of these symptoms, we can mention: increase or decrease in urinary frequency ( $<3$ urination/ day), incontinence, urgency, nocturia, effort, hesitation, dysuria, containment and retention maneuvers. Examples of intestinal symptoms are: incontinence, straining, bowel movement pain and functional constipation. In the absence of intestinal symptoms, the term lower urinary tract dysfunction (LUTD) is more appropriate ${ }^{1,2}$.

In epidemiological terms, the prevalence of LUTS is relevant. For example, in a study carried out in Lithuania, with a sample of 360 children and 388 adolescents treated at a children's hospital for problems not related to urination, it was found that $44.3 \%$ of those evaluated had LUTS, among them $34 \%$ had urgency, $24.6 \%$ urinary incontinence and $8.7 \%$ enuresis $^{3}$.

In the United Kingdom, in 2017,900,000 children and adolescents were living with enuresis, daytime urinary incontinence, encopresis and/or constipation. That is, at least two students in every classroom at every school across the UK had BBD 4 .

Each year in England, 15,000 children and adolescents are admitted to hospitals to be treated for chronic constipation and urinary tract infection, and $80 \%$ of these hospitalizations could be avoided, saving resources from that health system ${ }^{4}$.

As for the Brazilian reality, there are few studies that assess the prevalence of LUTS in school-age children. In a study carried out in Pelotas, when analyzing information from 3,602 children between 6 and 7 years old, urinary urgency (22.7\%) 
and containment maneuvers (38.2\%) were identified as the most prevalent symptoms. The prevalence of nocturnal enuresis was $10.6 \%$, being predominant in males 5 . These data are significant when considering the impacts that LUTS cause in children's lives.

Another study evaluated the perception of parents/guardians regarding the presence of these symptoms, and they believed that urinary leakage (90\%) and other symptoms (75\%) were due to the fact that the child was too lazy to go to the bathroom, not wanting to go to the bathroom and interrupt leisure activities, that is, the symptoms were voluntary. In addition, those responsible stated that they had already applied some punitive measure due to the presence of symptoms, with $85 \%$ reporting having already fought, $35 \%$ said they had already beaten and $50 \%$ reported that the child had already been subjected to embarrassing situations 6 .

At school age, between 6 and 17 years old, children and adolescents are emotionally and psychologically sensitive to the opinions of, and affected when they feel highlighted in embarrassing and failure situations. Physiological eliminations, being culturally taboo and veiled, are often part of the context for these embarrassing situations. Therefore, children and adolescents usually schedule eliminations for private moments, in which they are not afraid of being exposed, especially those who already have symptoms of $\mathrm{BBD}^{7,8}$.

The school period corresponds to half of the hours that students are awake. Thus, it is expected that they have an average of two to three urination episodes during the school day. However, at school, emotional and psychological needs and weaknesses are often not respected, causing most students to postpone and repress the urge to urinate or evacuate, making the school a risky environment for the development or worsening of LUTS and of intestinal symptoms ${ }^{7,8}$.

In view of the high prevalence of bladder and bowel symptoms in the chosen age group, it is possible to perceive the potential that the school and education professionals have in the observation and prevention of complications. In view of this, there was a need to investigate the prevalence of urinary and intestinal symptoms in the chosen scenario.

Given the above, it is hypothesized that elementary school children from municipal schools have considerable rates of urinary and/or intestinal symptoms. Thus, the objective of this study was to survey the occurrence of such symptoms in children enrolled in public elementary schools in a city in Paraná, Brazil.

\section{METHOD}

\section{Kind of study}

Exploratory-descriptive, cross-sectional study with a quantitative approach, carried out in two public schools in a city in the State of Paraná, Brazil.

\section{Population}

The study population consisted of parents and/or guardians of children enrolled in elementary schools in schools in the municipal education network of Curitiba.

\section{Selection criteria}

After approval by the Municipal Department of Education, 14 schools were pre-selected according to the ease of access by the researchers. Then, telephone contact was made with each of them, for presentation and request to carry out the research. Two agreed to participate. It is called E1, the school in the northern region of the city and E2 the school in the southern region. As a counterpart to the acceptance of the research, these two schools would receive, from the researchers, a 
lecture to teachers, parents and interested parties about BBD in children, prevention measures and simple treatment. Both schools, however, did not accept the offer of the lecture, justifying the difficulty of time and of bringing people together.

\section{Data collect}

For data collection, the Dysfunctional Voiding Scoring System (DVSS) instruments were used, which assess the severity of urinary symptoms, Rome IV criteria, to identify cases of Functional Intestinal Constipation, supported by the Bristol scale, to identify faecal consistency.

The DVSS is an instrument translated into Portuguese and cross-culturally validated for Brazilian reality. It assesses the occurrence of symptoms in the last 30 days, using a Likert scale, ranging from "never or almost never" (0 points) to "almost all the time" (3 points). The symptoms analyzed are: urinary urgency, incontinence and urinary frequency, effort and evacuation frequency, maneuvers of containment and effort and pain when urinating. The DVSS also assesses the environmental factor, considered to be child stressors. For this item, the score is zero when no factors are identified or three when one or more are identified. In addition to allowing the assessment of symptoms in isolation, the instrument allows the diagnosis of voiding dysfunction, when children or adolescents reach six (female) or nine (male) scores?.

The ROME IV criteria, published in 2016, present diagnostic criteria for Intestinal Dysfunction. The criteria for Functional Intestinal Constipation - FIC (C2) were used, which correspond to six "yes" or "no" questions related to signs and symptoms of constipation. The diagnosis of FIC is considered positive if two or more questions are marked as "yes". This instrument considers the occurrence of symptoms in the last 30 days and in at least $25 \%$ of bowel movements ${ }^{10}$.

The Bristol Scale is a visual representation of fecal consistency. The stools can have a consistency of 01 to 07 , and the lower the number, the more dry and the higher, the softer. The ideal is type four stools (elongated sausage or snake-shaped, smooth and soft). This scale has also been translated and validated for use in Brazil ${ }^{11}$.

An explanatory booklet on BBD in childhood was also prepared to clarify these dysfunctions for parents and guardians. The questionnaires, together with the free and informed consent form, in two copies, and the booklet were delivered by the researchers to the directors: 420 questionnaires for E1 and 414 for E2, which correspond to the number of children in the age group of the study, enrolled in each school. The directors gave the questionnaires to the teachers so that they could forward them to the parents via the child. A deadline (after two weeks) was agreed with the directors for returning the completed instruments.

\section{Data analysis and processing}

The questionnaires were transcribed into a Microsoft Excel spreadsheet and later analyzed using the computer program IBM SPSS Statistics v.20.0. Armonk, NY: IBM Corp. The results of quantitative variables were described by means, standard deviations, medians, minimum and maximum values. Categorical variables were described by frequencies and percentages. For the comparison of children aged up to 7 years and children older than 7 years, and also for the comparison of genders, in relation to the DVSS score, the non-parametric Mann-Whitney test was used. To assess the association between the ROME IV diagnosis (negative or positive) and age and gender, Fisher's exact test was used. p values $<0.05$ indicates statistical significance.

\section{Ethical aspects}

The research was approved by the Research Ethics Committee of the Pontifícia Universidade Católica do Paranáunder opinion No. 3,575,443, of 2019, respecting all standards and guidelines for research involving human beings, presented in Resolution 466/2012 of the National Health Council. 


\section{RESULTS}

Of the total of 834 questionnaires delivered to schools, 458 were returned (224 from E1 and 234 from E2). However, not all were completely filled. There was a failure to complete all instruments (DVSS, ROME IV Criteria and Bristol scale), in terms of age and gender of the child.

Of the total number of returned questionnaires, the DVSS was completed in 454, the ROME IV Criteria in 449 and the Bristol Scale in 446. Perhaps due to limitation or lack of clarity of the collection questionnaire, the biggest gap in filling was in gender and age. , with 185 filled in with information on gender and 84 with information on age. Therefore, 14.4\% ( $n=66)$ were completely filled. Therefore, in view of this significant sample loss, the authors chose to keep the total sample of the return and consider isolated analyses.

Of the 185 questionnaires with gender, 96 were for girls (51.9\%) and 89 were for boys (48.1\%). As for age, of the 84 completed questionnaires, the mean was 7.7 years, with a standard deviation of 1.6.

Of the total number of questionnaires received, 184 had the child's gender and DVSS answered. Of these, 16 boys had a score greater than 9, and 38 girls had a score greater than 6, concluding a diagnosis of voiding dysfunction for 54 children (29.3\%).

If we consider isolated DVSS symptoms, 375 , that is, $83 \%$ of the children $(n=454)$ had at least one urinary or intestinal symptom. Table 1 presents the percentage of occurrence of each symptom identified by the instrument, as well as the frequency of manifestation of this symptom.

Table 1.Occurrence of urinary symptoms in municipal elementary school children according to the Dysfunctional Voiding Scoring System. Curitiba (PR), Brasil - 2019.

\begin{tabular}{|c|c|c|}
\hline Question & Answer & n (\%) \\
\hline \multirow{4}{*}{$\begin{array}{l}1 \\
\text { Does your child have wet clothes from pee during the day? }\end{array}$} & 0 & $410(90.3)$ \\
\hline & 1 & $33(7.3)$ \\
\hline & 2 & $6(1.3)$ \\
\hline & 3 & $5(1.1)$ \\
\hline \multirow{4}{*}{$\begin{array}{l}2 \\
\text { When your child gets wet from pee } \\
\text { Are their underwear or panties soaking wet? }\end{array}$} & 0 & $418(92.1)$ \\
\hline & 1 & $24(5.3)$ \\
\hline & 2 & $8(1.8)$ \\
\hline & 3 & $4(0.9)$ \\
\hline \multirow{4}{*}{$\begin{array}{l}3 \\
\text { How often does your child not poop every day? }\end{array}$} & 0 & $227(50.0)$ \\
\hline & 1 & $117(25.8)$ \\
\hline & 2 & $79(17.4)$ \\
\hline & 3 & $31(6.8)$ \\
\hline \multirow{4}{*}{$\begin{array}{l}4 \\
\text { Does your child have to strain to poop? }\end{array}$} & 0 & $262(57.7)$ \\
\hline & 1 & 107 (23.6) \\
\hline & 2 & $51(11.2)$ \\
\hline & 3 & $34(7.5)$ \\
\hline \multirow{4}{*}{$\begin{array}{l}5 \\
\text { How often does your child only go to the bathroom to pee once or twice a day? }\end{array}$} & 0 & $182(40.1)$ \\
\hline & 1 & $44(9.7)$ \\
\hline & 2 & $143(31.5)$ \\
\hline & 3 & 85 (18.7) \\
\hline
\end{tabular}

continue... 
Tabela 1. Continuation...

\begin{tabular}{|c|c|c|}
\hline Question & Answer & n (\%) \\
\hline \multirow{4}{*}{$\begin{array}{l}6 \\
\text { Does your child hold his/her pee by crossing his/her legs, squatting or dancing? }\end{array}$} & 0 & 325 (71.6) \\
\hline & 1 & $73(16.1)$ \\
\hline & 2 & 31 (6.8) \\
\hline & 3 & $25(5.5)$ \\
\hline \multirow{4}{*}{$\begin{array}{l}7 \\
\text { When your child needs to pee, does he/she have to go to the bathroom quickly? (can't wait) }\end{array}$} & 0 & $302(66.5)$ \\
\hline & 1 & $76(16.7)$ \\
\hline & 2 & $38(8.4)$ \\
\hline & 3 & $38(8.4)$ \\
\hline \multirow{4}{*}{$\begin{array}{l}8 \\
\text { Does your child have to strain to pee? }\end{array}$} & 0 & $448(98.7)$ \\
\hline & 1 & $5(1.1)$ \\
\hline & 2 & $0(0.0)$ \\
\hline & 3 & $1(0.2)$ \\
\hline \multirow{4}{*}{$\begin{array}{l}9 \\
\text { Has your child said they feel pain when they pee? }\end{array}$} & 0 & $436(96.0)$ \\
\hline & 1 & $14(3.1)$ \\
\hline & 2 & $3(0.7)$ \\
\hline & 3 & $1(0.2)$ \\
\hline \multirow{2}{*}{$\begin{array}{l}10 \\
\text { Has your child been through a stressful situation in the last } 30 \text { days? }\end{array}$} & 0 & $364(80.2)$ \\
\hline & 3 & $90(19.8)$ \\
\hline
\end{tabular}

0: never or almost never; 1: less than half the time; 2: half time; 3: almost all the time; Except question 10, where 0 is no and 3 is yes.

The most prevalent LUTS was reduced voiding frequency (< 3 micturitions/day) (question 5): of the 454 questionnaires with the DVSS answered, 272 indicated this symptom (59.9\%). The second LUTS was urgent (question 7) with 33.5\% of positive responses. The other most prevalent symptom was containment maneuvers (question 6) with $28.4 \%$. The most prevalent bowel symptoms were reduced evacuation frequency (question 3), with a prevalence of 50.0\%, followed by evacuation effort (question 4), with a prevalence of $42.3 \%$. Regarding symptom severity, the arithmetic mean of the DVSS score of the 454 questionnaires was 4.7. Being 4.5 in E1 and 4.9 in E2.

Table 2 shows the association between the severity of symptoms identified by the DVSS and the characterization of the sample, with 184 questionnaires filled out with DVSS and gender, and 83 questionnaires with DVSS and age. It is observed that there was a statistically significant difference between the severity of symptoms in children aged 7 years or younger and the others.

Of the 449 questionnaires that met the Rome IV criteria, 178 (39.6\%) were positive for FIC, as they had two or more positive criteria in at least $25 \%$ of evacuations. No statistically significant difference was identified for FIC when cross-referencing the questionnaires with age and gender.

Analyzing the symptoms of the Rome IV Criteria separately, Table 4 shows the occurrence of each one. The most mentioned symptom was reduced frequency of bowel movements, followed by hard stools and defecation effort. 
Table 2. Association between severity of intestinal bladder dysfunction symptoms, age and gender in public elementary school children. Curitiba (PR), Brasil - 2019.

\begin{tabular}{|c|c|c|c|c|c|c|}
\hline \multirow{2}{*}{ Age (years) } & \multicolumn{5}{|c|}{ Score DVSS } & \multirow{2}{*}{$p^{*}$} \\
\hline & $\mathrm{n}$ & Average & Median & Minimum & Maximum & \\
\hline Up to 7 & 42 & 6.7 & 6 & 0 & 20 & \multirow{2}{*}{0.015} \\
\hline Over 7 & 41 & 4.5 & 4 & 0 & 16 & \\
\hline \multirow{2}{*}{ Gender } & \multicolumn{5}{|c|}{ Score DVSS } & \multirow{2}{*}{$p^{*}$} \\
\hline & $\mathrm{n}$ & Average & Median & Minimum & Maximum & \\
\hline Female & 96 & 5.4 & 4 & 0 & 20 & \multirow{2}{*}{0.350} \\
\hline Male & 88 & 4.9 & 3.5 & 0 & 18 & \\
\hline
\end{tabular}

*Non-parametric Mann-Whitney test, $p<0,05$. DVSS = Dysfunctional Voiding Scoring System.

Table 3. Occurrence of symptoms most prevalent according to gender, according to the Dysfunctional Voiding Scoring System. Curitiba (PR), Brasil - 2019.

\begin{tabular}{lll}
\hline Urinary symptoms & Percent & Frequency \\
\hline Girls ( $\mathbf{n}=\mathbf{9 6})$ & & 60 \\
\hline reduced urination frequency & 64.6 & 32 \\
\hline voiding urgency & 33.3 & 32 \\
\hline containment maneuvers & 33.3 & \\
\hline Boys (n=88) & & 44 \\
\hline reduced urination frequency & 49.4 & 33 \\
\hline voiding urgency & 37.1 & 20 \\
\hline containment maneuvers & 22.5 & \\
\hline Intestinal symptoms & & 53 \\
\hline Girls (n=96) & & 44 \\
\hline reduced evacuation frequency & 55.2 & 47 \\
\hline evacuation effort & 45.8 & 46 \\
\hline Boys (n=88) & & 52.8 \\
\hline reduced evacuation frequency & 51.7 & \\
\hline evacuation effort & & \\
\hline
\end{tabular}

Table 4. Prevalence of functional constipation symptoms according to Rome IV criteria in public elementary school children.Curitiba (PR), Brasil - 2019.

\begin{tabular}{|c|c|c|}
\hline Question & Answer. & $\mathrm{n}(\%)$ \\
\hline 1 & no & $327(72.8)$ \\
\hline Do you need to strain to poop? & yes & $122(27.2)$ \\
\hline 2 & no & $277(61.7)$ \\
\hline Is the poop dry or hard? & yes & $172(38.3)$ \\
\hline 3 & no & $350(78.0)$ \\
\hline Do you have the feeling that all the poop hasn't come out? & yes & $99(22.0)$ \\
\hline 4 & no & $416(92.7)$ \\
\hline Do you feel like there's something that won't let the poop out? & yes & $33(7.3)$ \\
\hline 5 & no & $445(99.1)$ \\
\hline Need help with your hand to get the poop out? & yes & $4(0.9)$ \\
\hline 6 & no & $268(59.7)$ \\
\hline Do you poop three times a week or less? & yes & $181(40.3)$ \\
\hline
\end{tabular}


Regarding the Bristol scale, completed in 446 questionnaires, Table 5 presents the percentage for each fecal consistency. It is noted that $71.7 \%$ of children have stools in formats considered ideal ( 3 and 4), but there is a tendency for dry stools compared to soft ones. There was no statistically significant difference in the comparison of fecal consistency when crossreferencing the questionnaires with age and gender.

Table 5. Prevalence of stool shape according to the Bristol scale in public elementary school children. Curitiba (PR), Brasil - 2019.

\begin{tabular}{cc}
\hline Bristol & $\mathbf{n}(\%)$ \\
\hline 1 & $29(6.5)$ \\
\hline 2 & $82(18.4)$ \\
\hline 3 & $212(47.5)$ \\
\hline 4 & $108(24.2)$ \\
\hline 5 & $10(2.2)$ \\
\hline 6 & $3(0.7)$ \\
\hline 7 & $2(0.4)$ \\
\hline Total & $446(100.0)$
\end{tabular}

As for psychosocial factors, of the 454 questionnaires answered in the DVSS, 67 marked question 10, that is, $14.8 \%$ of the children were submitted to some stressful situation in the last 30 days.

The situations marked and/or written down were: 29 pointed to problems at home ( 14 of them death of a family member, and 10 divorce), 21 pointed to moving house, 19 pointed to school problems, 18 marked special events ( 6 of them being the birthday ), 14 reported a new baby at home, 10 experienced a change of school and 2 rated abuse (one being sexual).

Considering that IBD is the presence of voiding dysfunction added to FIC, of the 54 children who presented voiding dysfunctions, 35 were constipated, totaling 35 children with BBD. Of this total of children with BBD, 23 (65.7\%) were female and $12(34.3 \%)$ were male.

\section{DISCUSSION}

The occurrence of urinary or intestinal symptoms was $83 \%$, a higher rate than a study that identified a prevalence of 44\%3. It is worth mentioning that the rates were similar between the two investigated schools. Analyzing the prevalence compared to gender, most studies point to a higher prevalence of BBD symptoms in female children ${ }^{3,6}$, however, a study was found in which the prevalence was higher in male children ${ }^{5}$. If the results found in the present study were analyzed, there was no statistically significant difference, being similar in both genders. However, if the symptoms of reduced voiding frequency and retention maneuvers are considered alone, the prevalence was higher in girls.

Still considering LUTS in isolation, the present study identified reduced voiding frequency ( $<3$ micturitions/day) as the most prevalent symptoms. This result differs from other studies, which identified voiding urgency as more prevalent in school-age children. ${ }^{3,5,6}$. Studies found in the literature address the impact that bathrooms in the school environment have on students, causing eliminations to be postponed.

It is worth mentioning that the finding of low voiding frequency may be related to low fluid intake during the period in educational activities. However, the factors highlighted by the studies are related to infrastructure, lack of privacy to use the bathrooms, ideal time for elimination, going to the bathroom during classes, feeling of insecurity and bullying ${ }^{7,8}$. In addition to these points, the hygiene of the environment impacts students, who often find themselves with toilet paper on the floor, full and overflowing bins, urine on the toilet seat and on the floor, bad odor, dirty and wet sinks, lack of paper and soap ${ }^{8}$.

When analyzing the children who presented DVSS consistent with voiding dysfunction ( $\mathrm{n}=54$ children), a higher prevalence of urgency symptoms (64.8\%), followed by containment maneuvers (61.1\%) and incontinence (24.1\%) was identified. \%). This data corroborates data found in the literature in a study carried out with children with LUTD (sample 
of 22 children), in which the author identified that the most prevalent symptoms were urge incontinence (81\%), followed by containment maneuvers (77.3\%) and enuresis (59.1\%). When the affected gender was evaluated, the dysfunctions were more present in females $(90.9 \%)^{6}$.

When comparing the DVSS scale scores for urinary symptoms and the presence of constipation (positive Rome IV), the high prevalence of FIC in children was evidenced, regardless of the DVSS score. In other studies, an association was identified between high DVSS scores with constipation ${ }^{12-14}$.

Studies found in the literature evaluated the association between a higher DVSS score and psychosocial stressors presented by children. This association was observed in $37 \%{ }^{15}$ to $60 \%{ }^{16}$ of the cases. In the present study, some situations considered stressful for children were identified, such as problems at home (parental divorce and death of a family member), school problems, special events (birthday), moving house, new baby at home, changing school and abuse. .

In addition to the fact that changes and/or emotional stress increase the presence of LUTS, it is also important to emphasize that the presence of these symptoms can lead to emotional and social problems. In this study, no statistically significant association was found between stress situations and the occurrence of urinary or intestinal symptoms or an increase in the DVSS score, since only $19.8 \%$ of the children scored question 10 of the instrument.

The results of this study were consistent with the literature. IBD affect a significant percentage of healthy children. These children are exposed to the complications of BBD, such as moisture-associated dermatitis, incomplete bladder emptying, urinary tract infection (UTI) and vesicoureteral reflux, which jeopardizes upper urinary tract function ${ }^{7,8}$.

In addition to these physical consequences, children with BBD are more likely to develop behavioral and psychosocial changes, as they are often exposed to embarrassing situations, which limit social life, lower self-esteem and compromise school performance ${ }^{1,2}$.

The globally recognized way to prevent BBD and considered the first line of treatment is urotherapy. It consists of a non-surgical and non-pharmacological approach that involves educating the child/adolescent and their caregivers/family regarding urinary tract function, fluid and fiber intake, urinary habits, interval between urinations and positioning on the toilet $^{1,2}$. In addition to being simple, urotherapy is effective in reducing symptoms and resolving most cases ${ }^{2}$.

It is necessary a strong dissemination of knowledge about the symptoms of BBD and preventive and control measures among the population, especially the school community. Considering that all children of age to manifest BBD are of school age and must be enrolled in elementary school, the teacher becomes a key professional in the school for the identification of a possible problem ${ }^{8}$.

Despite the need for nurses to participate in this process of identifying children with urinary and intestinal symptoms and/or providing guidance to teachers, the current scenario shows a certain difficulty and resistance of these nursing professionals to enter the school context. In the present study, only two schools agreed to participate in the research, but they did not authorize the holding of the educational lecture that would be offered to parents, guardians and teachers with guidance on the subject. Therefore, we can see the importance of the topic being addressed in the different environments in which children are inserted, including schools, allowing greater interaction between the areas of education and health.

If teachers know how to identify symptoms of BBD, they can guide measures and even refer the child to a specialized service. On the other hand, if they know what are the measures that prevent such manifestations, they can, through their guidelines, reduce the prevalence of the problem in the school environment ${ }^{8}$.

According to the Federal Council of Nursing (Conselho Federal de Enfermagem-COFEN) and the law of professional practice, one of the nurse's attributions is to participate in health education activities with the objective of improving the health of the individual, family and community ${ }^{17}$. Therefore, the nurse as a health education agent appears in this scenario with the possibility of training teachers and being references for the connection between school and health service ${ }^{8}$.

In addition to the educational and orienting participation of nurses, it is also their responsibility to act in the face of urinary and intestinal incontinence, as well as to participate in the reeducation of urination and evacuation habits ${ }^{17}$. Within the nurses' specialties, the importance of the stomatherapist nurse stands out. This professional works, among one of his three areas, with the area of incontinence. In this aspect, the stomatherapist nurse aims to evaluate patients with 
urinary and/or intestinal alterations, through instruments and physical examination, as well as to act for the prevention and treatment of these alterations ${ }^{18}$.

As for the limitations of this study, it is considered that the completion of the form by parents and guardians was a complicating factor. This is because many forms were not completed, others were incomplete, and in others, difficulties in understanding the question (specifically in relation to the DVSS) were noted, which may have interfered with the answer. This barrier considerably reduced the sample. For future research, it is suggested to compare the occurrence of symptoms with the children's relationship with the school and with the teachers' knowledge and attitude on the subject.

\section{CONCLUSION}

There was a high occurrence of urinary and intestinal symptoms in children enrolled in the municipal elementary school network in two schools in Paraná, as more than $83 \%$ of the sample had at least one urinary and/or intestinal symptom, regardless of the severity of this symptom. It can be seen that BBD are present in healthy school-age children. In the present study, of the children who presented voiding symptoms, more than half also had FIC, confirming a diagnosis of BBD.

The most prevalent urinary symptoms were reduced voiding frequency, voiding urgency and retention maneuvers. The most prevalent intestinal symptoms were reduced evacuation frequency and evacuation effort, consistent with the high occurrence of functional constipation diagnosis (positive Rome IV criteria).

There was a statistically significant difference for the DVSS score between children older than and younger than 7 years, but this difference was not observed between both genders. Girls, however, had a higher occurrence of reduced voiding frequency and retention maneuvers than boys.

It was identified that school-aged children have significant urinary and intestinal symptoms, which is a real problem and, in most cases, undiagnosed and untreated. Preventive and corrective action is necessary in the face of this problem, and the nurse is the professional who presents technical-scientific and legal knowledge to work with this population.

\section{AUTHORS' CONTRIBUTION}

Conceptualization: Miranda JNR, Silva CPC, Assis GM and Martins G; Investigation: Miranda JNR and Silva CPC; Writing - First version: Miranda JNR, Silva CPC and Arruda DF; Writing - Reviewing \& Editing: Miranda JNR, Silva CPC and Arruda DF; Resources: Miranda JNR and Silva CPC; Supervision: Assis GM and Martins G.

\section{DATA STATEMENT AVAILABILITY}

Not applicable.

\section{FUNDING}

Not applicable.

\section{ACKNOWLEDGEMENT}

Not applicable.

\section{REFERENCES}

1. Austin PF, Bauer SB, Bower W, Chase J, Franco I, Hoebeke P et al. The standardization of terminology of lower urinary tract function in children and adolescents: Update report from the standardization committee of the International Children's Continence Society. Neurourol Urodyn. 2016;35(4):471-81. https://doi.org/10.1002/nau.22751 
2. Santos J, Lopes RI, Koyle MA. Bladder and bowel dysfunction in children: An update on the diagnosis and treatment of a common, but underdiagnosed pediatric problem. Can Urol Assoc J. 2017;11(1-2Supl1):S64-72. https://doi.org/10.5489/ cuaj.4411

3. Jankauskienė A, Vaičiūnienè D, Stacevičienè I. Prevalence of lower urinary tract symptoms in Vilnius area children and adolescents. Acta Med Litu. 2014; 21(1):27-33. https://doi.org/10.6001/actamedica.v21i1.2886

4. ERIC, The Children's Bowel \& Bladder Charity [internet] Bristol: ERIC, The Children's Bowel \& Bladder Charity; [Cited 2019 feb 19]. ERIC's strategic plan 2017-2020; 2017. Available at: https://www.eric.org.uk/Handlers/Download.ashx?IDMF=c7a02cd31374-49ea-84b7-0b99d56cf4c3

5. Mota DM, Barros AJD, Matijasevich A, Santos IS. Prevalence of enuresis and urinary symptoms at age 7 years in the 2004 birth cohort from Pelotas, Brazil. J Pediatr. 2015; 91(1):52-8. https://doi.org/10.1016/j.jped.2014.04.011

6. Veloso LA, de Mello MJG, Neto JPMR, Barbosa LNF, e Silva EJC. Qualidade de vida, nível cognitivo e desempenho escolar em crianças portadoras de distúrbio funcional do trato urinário inferior. J Bras Nefrol. 2016;38(2):234-44. http://doi. org/10.5935/0101-2800.20160033

7. Tatlow-Golden M, O'Farrelly C, Booth A, Doyle O. “Bursting” to Go and Other Experiences: Children's Views on Using the Toilet in the First School Year. J Sch Nurs. 2017;33(3):214-22. https://doi.org/10.1177/1059840516646422

8. Norling M, Stenzelius K, Ekman N, Wennick A. High School Students' Experiences in School Toilets or Restrooms. J Sch Nurs. 2016;32(3):164-71. https://doi.org/10.1177/1059840515611476

9. Calado AA, Araujo EM, Barroso U, Netto JMB, Filho MZ, Macedo A et al. Crosscultural adaptation of the dysfunctional voiding score symptom (DVSS) questionnaire for Brazilian children. Int Braz J Urol. 2010;36(4):458-63. https://doi.org/10.1590/S167755382010000400009

10. Lacy BE, Mearin F, Chang L, Chey WD, Lembo AJ, Simren M et al. Bowel Disorders. Gastroenterology. 2016;150(6):1393-407. https://doi.org/10.1053/j.gastro.2016.02.031

11. Martinez AP, Azevedo GR. Tradução, adaptação cultural e validação da bristol stool form scale para a população brasileiro. Rev Lat-Am Enfermagem. 2012;20(3):583-9. http://doi.org/10.1590/S0104-11692012000300021

12. Sampaio C, Sousa AS, Fraga LGA, Veiga ML, Netto JMB, Barroso U. Constipation and Lower Urinary Tract Dysfunction in Children and Adolescents: A Population-Based Study. Front Pediatr. 2016;4. https://doi.org/10.3389/fped.2016.00101

13. Zeevenhooven J, Koppen IJN, Benninga MA. The New Rome IV Criteria for Functional Gastrointestinal Disorders in Infants and Toddlers. Pediatr Gastroenterol Hepatol Nutr. 2017;20(1):1-13. http://doi.org/10.5223/pghn.2017.20.1.1

14. Hodges SJ. Enema Regimen in Pediatric Bladder Dysfunction. Curr Bladder Dysfunct Rep. 2017;12(3):225-8. https://doi. org/10.1007/s11884-017-0447-y

15. Wolfe-Christensen C, Guy WC, Mancini M, Kovacevic LG, Lakshmanan Y. Evidence of Need to Use Self-Report Measures of Psychosocial Functioning in Older Children and Adolescents with Voiding Dysfunction. J Urol. 2016;195(5):1570-4. https://doi. org/10.1016/j.juro.2015.11.045

16. Logan BA, Correia K, McCarthy J, Slattery MJ. Voiding dysfunction related to adverse childhood experiences and neuropsychiatric disorders. J Pediatr Urol. 2014;10(4):634-8. https://doi.org/10.1016/j.jpurol.2014.06.012

17. Conselho Federal de Enfermagem (COFEN). Parecer $n^{\circ}$ 04/2016/CTAS/COFEN. Manifestação sobre procedimentos da área de enfermagem [Internet]. Brasília: 2016. Available at: http://www.cofen.gov.br/parecer-no-042016ctascofen_45837.html

18. Associação Brasileira de Estomaterapia [internet]. São Paulo: Associação Brasileira de Estomaterapia; c2016 [Cited 2020 Jan 14]. Competências do enfermeiro estomaterapeuta;. Available at: http://sobest.provisorio.ws/textod/19 